\title{
Solid dispersion of meloxicam: Factorially designed dosage form for geriatric population
}

\author{
DEEPA PATHAK \\ SUNITA DAHIYA \\ KAMLA PATHAK* \\ Department of Pharmaceutics \\ Rajiv Academy for Pharmacy \\ Mathura, U.P. 281001, India
}

Accepted November 28, 2007

\begin{abstract}
The objective of the present work was to improve the dissolution properties of the poorly water-soluble drug meloxicam by preparing solid dispersions with hydroxyethyl cellulose (HEC), mannitol and polyethylene glycol (PEG) 4000 and to develop a dosage form for geriatric population. Differential scanning calorimetry, X-ray diffractometry, Fourier transform infrared spectroscopy and scanning electron microscopy were used to investigate the solid-state physical structure of the prepared solid dispersions. Higher in vitro dissolution of solid dispersions was recorded compared to their corresponding physical mixtures and the pure drug. PEG 4000 in 1: 9 drug to carrier ratio exhibited the highest drug release $(100.2 \%)$, followed by mannitol $(98.2 \%)$ and HEC $(89.5 \%)$ in the same ratio. Meloxicam-PEG 4000 solid dispersion was formulated into suspension and optimization was carried out by $2^{3}$ factorial design. Formulations containing higher levels of methyl cellulose and higher levels of either sodium citrate or Tween 80 exhibited the highest drug release.
\end{abstract}

Keywords: meloxicam, solid dispersion, hydroxyethyl cellulose, mannitol, polyethylene glycol 4000, $2^{3}$ factorial design, geriatric formulation

Meloxicam is 4-hydroxy-2-methyl- $N$-[ (5-methyl-1,3-thiazol-2-yl)-2H-1,2-benzothiazine-3-carboxamide-1,1-dioxide. It is a COX-2 inhibitor used to treat joint diseases such as osteoarthritis, rheumatoid arthritis and other musculoskeletal disorders. It is practically insoluble in water and its solubility increases significantly with an increase in $\mathrm{pH}$ (1). The enhancement of oral bioavailability of poorly water-soluble drugs remains one of the most challenging aspects of drug development although salt formation, solubilization and particle size reduction have commonly been used to increase the dissolution rate and thereby oral absorption and bioavailability of such drugs. Preparation of solid dispersions using water soluble carriers is yet another popular approach used to improve the oral bioavailability of poorly water soluble drugs. Among the various carriers

\footnotetext{
* Correspondence, email: kamla_rap@yahoo.co.in
} 
used, hydroxyethyl cellulose (HEC), mannitol and polyethylene glycol (PEG) 4000 are widely used because of their hydrophilicity, low melting point and low toxicity (2) and are inexpensive and readily available.

Solid dispersions (SD) with superior pharmaceutical properties can be formulated into suitable dosage forms especially for geriatric population which exhibits variable drug responses due to many age related physiological changes coupled with disease states. Geriatric patients with lower GI motility and gastric emptying, fluctuating gastric $\mathrm{pH}$ and reduced intestinal blood flow rate exhibit variable absorption upon administration of solid dosages forms. Hence, a liquid dosage form of the poorly water soluble drug meloxicam, keeping in mind the glucose intolerance experienced by geriatric patients, will overcome the absorption related problems of the poorly absorbed drug and will be a preferred dosage form.

EXPERIMENTAL

\section{Materials and methods}

Meloxicam was kindly supplied by Boehringer Ingelheim Pharmaceutical Inc. (Mexico), polyethylene glycol 4000 and mannitol were from Ranbaxy Fine Chemicals Limited (India), hydroxyethyl cellulose from Central Drug House (P) Ltd. (India) and $\mathrm{N}, \mathrm{N}$-dimethylformamide from Qualikems Fine Chemicals (India).

Solubility studies. - An excess amount of meloxicam was added to a $25-\mathrm{mL}$ conical flask containing different amounts of various carriers and $10 \mathrm{~mL}$ of distilled water, placed in a mechanical shaker at $37 \pm 0.5^{\circ} \mathrm{C}$ for $72 \mathrm{~h}$. At the end of 24,48 and $72 \mathrm{~h}$ samples were filtered, suitably diluted and analyzed for equilibrium solubility at $363 \mathrm{~nm}$ (3).

Solid dispersions preparation. - Solid dispersions of meloxicam were prepared with three water soluble carriers in different ratios (1:1, 1:5 and 1:9) by using three different methods, namely with HEC by the solvent evaporation method, with mannitol by the melting method and with PEG 4000 by the melting solvent method. Meloxicam and HEC were mixed and dissolved in $0.5 \mathrm{~mL}$ of dimethylformamide (4) (class 2 solvent, ICH Q3C guidelines).

The solvent was removed by evaporation at $50{ }^{\circ} \mathrm{C}$ for $30 \mathrm{~min}$ until constant mass was obtained. The dried dispersion was passed through a sieve no. $40(0.42 \mathrm{~mm})$ and stored in desiccator under vacuum for $12 \mathrm{~h}$. For preparation of the meloxicam PEG 4000 dispersion, accurately weighed meloxicam was dissolved in $1 \mathrm{~mL}$ of dimethylformamide and the drug solution was poured into melted PEG 4000 with continuous stirring. Cooling under ambient conditions was followed by drying under vacuum, sifted through a sieve no. $40(0.42 \mathrm{~mm})$ and the product was stored in desiccator under vacuum for $24 \mathrm{~h}$ to ensure complete removal of residual solvent. Meloxicam mannitol solid dispersion was prepared by passing both ingredients through a sieve no. $40(0.42 \mathrm{~mm})$, heating on an oil bath at $175 \pm 2{ }^{\circ} \mathrm{C}$ until they melted completely. Solidification was reached by cooling to room temperature under ambient conditions. The solidified mixture was pulverized in a glass pestle mortar, passed through sieve no. $40(0.42 \mathrm{~mm})$ and stored in desiccator. 
Preparation of physical mixtures. - Physical mixtures (PM) were obtained by blending the components in a glass mortar. Meloxicam and three different carriers in three different ratios, 1:1, 1:5 and 1:9, were accurately weighed and passed through a sieve no. 40 $(0.42 \mathrm{~mm})$, mixed well in the mortar, shifted through the same sieve and stored in desiccator under vacuum (5).

Drug content determination. - Ten mg of solid dispersion was accurately weighed and dissolved in $10 \mathrm{~mL}$ of methanol and filtered. Sample $(1 \mathrm{~mL})$ was diluted with methanol up to $10 \mathrm{~mL}$ and absorbance was measured with a UV spectrophotometer (Pharmaspec 1700, Shimadzu, Japan) at $363 \mathrm{~nm}$. The meloxicam content was calculated using the calibration curve $\left(R^{2}=0.9999\right)$.

\section{Dissolution studies}

Dissolution of meloxicam from various solid dispersion systems was studied in 0.01 molar phosphate buffer (6) (disodium hydrogen phosphate + sodium dihydrogen phosphate $\mathrm{pH} 7.5$ ) using a USP apparatus 2 (paddle type) dissolution rate test apparatus (7). Samples equivalent to $7.5 \mathrm{mg}$ of meloxicam were used in each test at $75 \mathrm{rpm}$ and temperature $37 \pm 0.5{ }^{\circ} \mathrm{C}$. Samples $(5 \mathrm{~mL})$ were withdrawn at predetermined time intervals, immediately replaced with fresh dissolution medium and analyzed for meloxicam content at $363 \mathrm{~nm}$ after suitable dilution. Percent of meloxicam dissolved at various time intervals was calculated from the regression equation generated from the suitably constructed calibration curve.

Differential scanning calorimetry (DSC). - DSC was performed on meloxicam and its solid dispersion using a Perkin Elmer DSC-7 differential scanning calorimeter (Perkin Elmer, USA) equipped with a liquid nitrogen sub ambient accessory (Perkin-Elmer). The instrument operated under nitrogen purge gas at a rate of $20 \mathrm{~mL} \mathrm{~min}^{-1}$. Samples (1-8 $\mathrm{mg}$ ) were sealed in alumina pans (TA instruments, Belgium) and heated at a scanning rate of $10{ }^{\circ} \mathrm{C} \mathrm{min}^{-1}$ from 20 to $400{ }^{\circ} \mathrm{C}$.

$X$-ray diffraction $(X R D)$. - The crystallinity of samples chosen for DSC was investigated by XRD using a Bruker diffractometer (WI 1140, Japan) and Cu-k $\alpha$ radiation. The diffractograms were run at $2.5^{\circ} \mathrm{C} \mathrm{min}-1$ and a chart speed of $2^{\circ} / 2 \mathrm{~cm}$ per $2 \theta$ angle.

Fourier transform infrared spectroscopy (FTIR). - Meloxicam and its solid dispersions were further characterized by FTIR. Samples prepared in $\mathrm{KBr}$ discs were subjected to FTIR recording on FTIR-8400S, CE (Shimadzu, Japan) instrument (SEM). Data were collected over a spectral range of 4000 to $400 \mathrm{~cm}^{-1}$.

Scanning electron microscopy (SEM). - SEM photographs of meloxicam and its solid dispersions with PEG 4000 were obtained using a ZEISS EVO 50 RONTEC X Flash detector type 1106 serial no. 0846 (Zeiss, USA), with $10^{-8} \mathrm{~m}$ thickness, silver coating by sputter coater E5100 UK POLARON.

Formulation and optimization of oral suspension. - Meloxicam to PEG 4000 (1:9) solid dispersion that exhibited maximum dissolution was selected for designing the geriatric dosage form. Oral suspension was selected as the preferred formulation and optimiza- 
D. Pathak et al.: Solid dispersion of meloxicam: Factorially designed dosage form for geriatric population, Acta Pharm. 58 (2008) 99-110.

Table I. Layout of $2^{3}$ factorial design and dependent responses for formulated suspensions using F18

\begin{tabular}{lccccc}
\hline $\begin{array}{l}\text { Formulation } \\
\text { code }\end{array}$ & $\begin{array}{c}\text { Tween } 80 \\
(\%, m / V)\end{array}$ & $\begin{array}{c}\text { Methyl cellulose } \\
(\%, m / V)\end{array}$ & $\begin{array}{c}\text { Sodium citrate } \\
(\%, m / V)\end{array}$ & $\begin{array}{c}\text { Viscosity at } 100 \\
\text { rpm (Pa s) }\end{array}$ & $\begin{array}{c}\text { Sedimentation } \\
\text { volume after } 72 \mathrm{~h}\end{array}$ \\
\hline S1 & 0.05 & 0.5 & 1.0 & 32 & 0.54 \\
S2 & 0.10 & 0.5 & 1.0 & 30 & 0.59 \\
S3 & 0.05 & 1.0 & 1.0 & 34 & 0.46 \\
S4 & 0.10 & 1.0 & 1.0 & 42 & 0.11 \\
S5 & 0.05 & 0.5 & 2.0 & 26 & 0.46 \\
S6 & 0.10 & 0.5 & 2.0 & 32 & 0.53 \\
S7 & 0.05 & 1.0 & 2.0 & 36 & 0.29 \\
S8 & 0.10 & 1.0 & 2.0 & 38 & 0.65 \\
\hline
\end{tabular}

tion studies of the formulation were carried out using $2^{3}$ factorial design (Table I) Three independent variables selected were Tween 80, methylcellulose (2000 Pa s) and sodium citrate at higher and lower levels. The dependent variables were viscosity and sedimentation volume. An accurately weighed quantity of solid dispersion was levigated with Tween 80 to form a smooth paste (8). Methylcellulose and xanthan gum, previously soaked in water for $1 \mathrm{~h}$, were added in divided portions to get a homogeneous preparation. Sodium benzoate, sodium citrate, sweetener and flavor in aqueous vehicle were incorporated to get the final suspension.

Evaluation of suspensions. - For single point viscosity determination of the suspensions, a Brookfield viscometer DV II+Pro viscometer (Brookfield engineering laboratories, MAO 2345, USA) attached to the spindle RV No. 4, was used at $24{ }^{\circ} \mathrm{C}$ and $100 \mathrm{rpm}$. The sedimentation volumes were described in terms of the percentage of the equilibrium settled height $\left(\mathrm{H}_{\mathrm{u}}\right)$ after storage at room temperature for $72 \mathrm{~h}$ to the original height (9).

The in vitro drug release studies of the optimized suspensions were performed in distilled water and 0.01 molar phosphate buffer $\left(\mathrm{pH} 7.5\right.$, at $37 \pm 0.5^{\circ} \mathrm{C}$ ) using a rotating dialysis cell apparatus at $75 \mathrm{rpm}$. The basket element of the apparatus was replaced by dialysis bag of Hi media 150 (Hi media laboratories, India) containing $5 \mathrm{~mL}$ of suspension. Samples were withdrawn at predetermined intervals, suitably diluted and analyzed at $363 \mathrm{~nm}(10)$.

\section{RESULTS AND DISCUSSION}

\section{Screening of carriers}

The carriers were selected on the basis of solubility and dissolution data. Solubility studies indicated an arithmetic increase in the solubility of meloxicam on increasing the concentration from 0.25 to $1 \%(\mathrm{~m} / \mathrm{m})$ for all of the carriers used (Fig. 1) in preparation of solid dispersion. The solubility of meloxicam $\left(0.014 \mathrm{mmol} \mathrm{L}^{-1}\right)$ increased to the value of $1.74,1.93$ and $2.64 \mathrm{mmol} \mathrm{L}^{-1}$ in the presence of $1 \%(\mathrm{~m} / \mathrm{m})$ of HEC, mannitol and PEG 
Fig. 1. Solubility profile of drug with different carriers: HEC (•), mannitol $(\bullet)$, PEG $4000(\boldsymbol{\Delta})$ (mean $\pm \mathrm{SD}, n=3$ ).

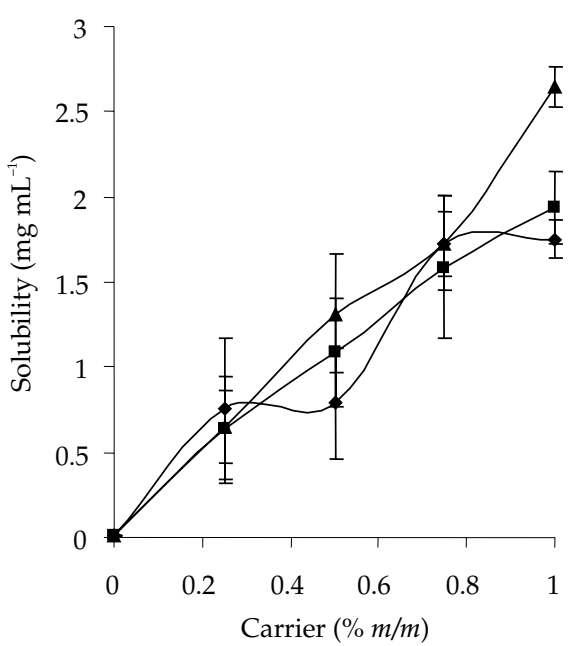

4000 respectively. Maximum solubility enhancement with PEG 4000 can be attributed to either solubilization of the drug or enhancement of the physical amorphism of meloxicam.

The in vitro profiles of the drug, physical mixture and solid dispersions are shown in Fig. 2. The drug exhibited a slow dissolution, suggesting that its absorption in vivo would be dissolution rate limited, whereas solid dispersions showed a marked enhancement in dissolution rate. Thus, dissolution of up to $100 \%$ was recorded with solid dispersions in contrast to the enhancement of $53.3 \%$ observed with physical mixtures. Further, the dissolution profile of solid dispersions in three different mixing ratios also demonstrated variability and it was found to be dependent on the drug-carrier ratio. Hence, as the proportion of carriers in the solid dispersion increased, the dissolution rate also increased. For all the carriers used, maximum dissolution was documented for the drug to the carrier ratio of 1:9 (F6, F12, F18). Among these, F18 made with PEG 4000 exhibited maximum release compared to F6 and F12 made with HEC and mannitol respectively. Based on XRD and SEM characterization (Figs. 3 and 4, discussed later in the text) typical mechanisms for improvement of dissolution characteristics of solid dispersions of the drug are particle size reduction, reduced crystallinity and total dispersibility in the carrier.

The dissolution data was subjected to model fitting (11). The dissolution of meloxicam alone and that from F12 and F18 obeyed the Weibull model $\left(R^{2}=0.946\right.$ and 0.948 respectively) whereas F6 followed the Hixon-Crowell cube root dissolution rate model $\left(R^{2}\right.$ $=0.9642$ ). The value of shape parameter was determined as $b<1$, for all the SDs which is consistent with the obtained release profile of higher initial slope followed by exponential release. For the pharmaceutical systems following the Weibull model, the logarithm of the dissolved amount of drug vs. the logarithm of time plot will be linear. For the formulation F6 obeying the Hixon-Crowell cube root model, the release rate will be limited by the drug particles dissolution rate. 


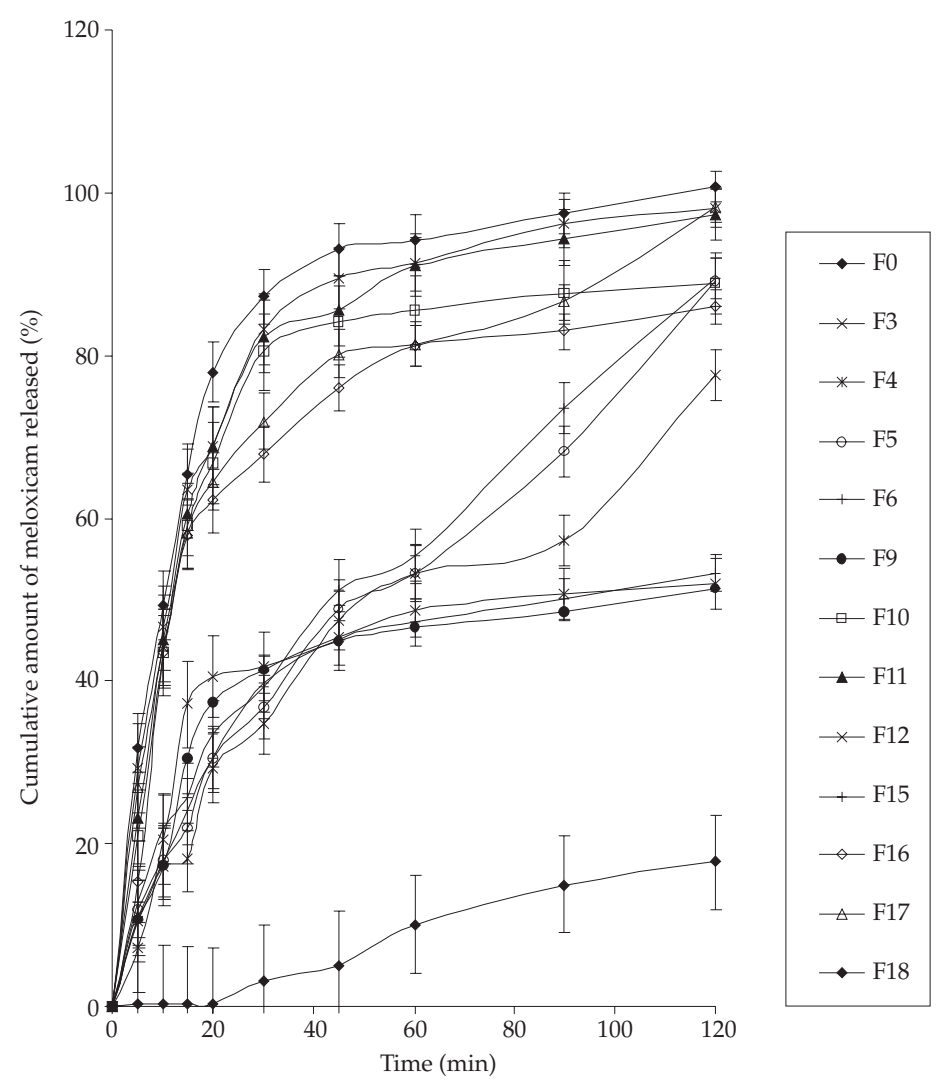

F0: Meloxicam, F3: drug to HEC, 1:9 physical mixture, F4: drug to HEC, 1:1 solid dispersion, F5: drug to HEC, 1:5 solid dispersion, F6: drug to HEC, 1:9 solid dispersion F9: drug to mannitol, 1:9 physical mixture, F10: drug to mannitol, 1:1 solid dispersion, F11: drug to mannitol, 1:5 solid dispersion, F12: drug to mannitol, 1:9 solid dispersion, F15: drug to PEG 4000, 1:9 physical mixture, F16: drug to PEG 4000, 1:1 solid dispersion, F17: drug to PEG 4000, 1:5 solid dispersion, F18: drug to PEG 4000, 1:9 solid dispersion
Fig. 2. Comparative dissolution graphs of dispersions, physical mixtures and meloxicam: (mean \pm $\mathrm{SD}, n=3)$.

Comparison of model independent dissolution parameters, namely $t_{50 \%}, t_{90 \%}$ and dissolution efficiency at $30 \mathrm{~min}$ and $120 \mathrm{~min}$ (Table II) clearly indicated that F18 required least time to release $50 \%$ and $90 \%$ of the drug compared to $\mathrm{F} 6$ and $\mathrm{F} 12$ and also exhibited maximum dissolution efficiency of 63 and $86 \%$ at $30 \mathrm{~min}$ and $120 \mathrm{~min}$ respectively. Thus, F18 was selected for formulation of the suspension.

\section{Solid state characterization}

The DSC thermogram (Fig. 5) of meloxicam exhibited a sharp endothermic peak at $260{ }^{\circ} \mathrm{C}$, corresponding to its melting point. When physically mixed with meloxicam, PEG recorded a shift of the endothermic peak to $146^{\circ} \mathrm{C}$, which may be attributed to the 
Fig. 3. XRD thermograms: a) meloxicam, b) PEG 4000 c) meloxicam/PEG physical mixture and d) meloxicam/ PEG solid dispersion.

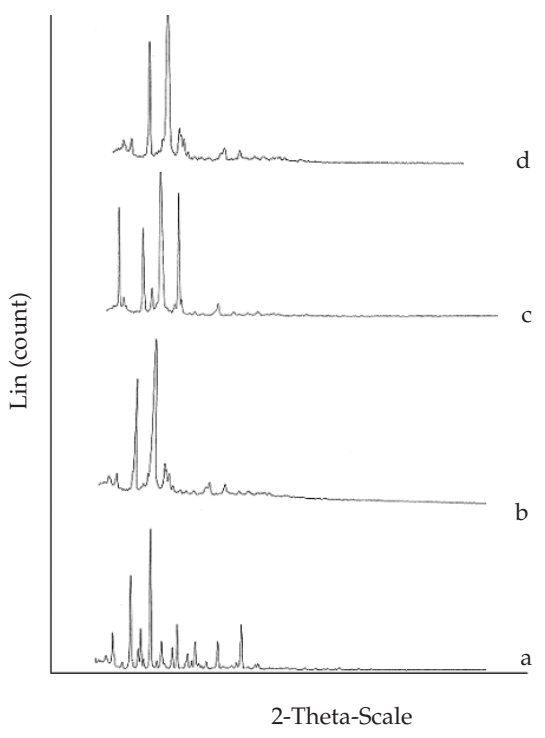

presence of PEG in the molten state, which caused the lowering of the melting point of the drug. In case of F18, a further reduction to $61{ }^{\circ} \mathrm{C}$ may be attributed to formation of the eutectic system, whereby a microfine dispersion of the two components with a concomitant decrease in melting point was observed on cooling the molten mix (12). However, the endothermic peak observed for F18 was diffuse and broad ( $\left.213 \mathrm{~mJ} \mathrm{mg}^{-1}\right)$ compared to the sharp intense peak $\left(232 \mathrm{~mJ} \mathrm{mg}^{-1}\right)$ of the carrier alone thus confirming the formation of SD.

The X-ray diffractograms (Fig. 3) of meloxicam showed numerous distinctive peaks that indicated high crystallinity. In the physical mixture, the distinctive diffraction peaks of meloxicam persisted with a marked decrease in their intensity compared to pure meloxicam crystals. The solid dispersion F18 exhibited lesser and broader peaks, indicating that the drug was present in the amorphous form in the dispersion.

The drug showed peaks at $3291.9 \mathrm{~cm}^{-1}$ for $\mathrm{NH}, 2918.4 \mathrm{~cm}^{-1}$ for $\mathrm{CONH}, 1619.9 \mathrm{~cm}^{-1}$ for $\mathrm{SO}_{2}, 1528.1 \mathrm{~cm}^{-1}$ for $\mathrm{C}=\mathrm{C}$ and peaks between 527.2 and $1452.9 \mathrm{~cm}^{-1}$ characteristic aromatic ring. Physical mixtures exhibited peaks of the drug and the carriers. The IR spectra (Fig. 6) of F18 exhibited characteristic drug peaks and additional new peaks.

Table II. Model independent parameters of selected solid dispersions of meloxicam

\begin{tabular}{llcccc}
\hline Formulation code & Composition & $t_{50 \%(\min )}$ & $t_{90 \%(\min )}$ & $D E_{30 \min }(\%)$ & $D_{120 \text { min }}(\%)$ \\
\hline F6 & Drug/HEC, 1:9 SD & 43 & 120 & 66.01 & 83.31 \\
F12 & Drug/mannitol, 1:9 SD & 12 & 72 & 69.01 & 83.90 \\
F18 & Drug/PEG 4000, 1:9 SD & 11 & 35 & 63.12 & 86.85 \\
\hline
\end{tabular}



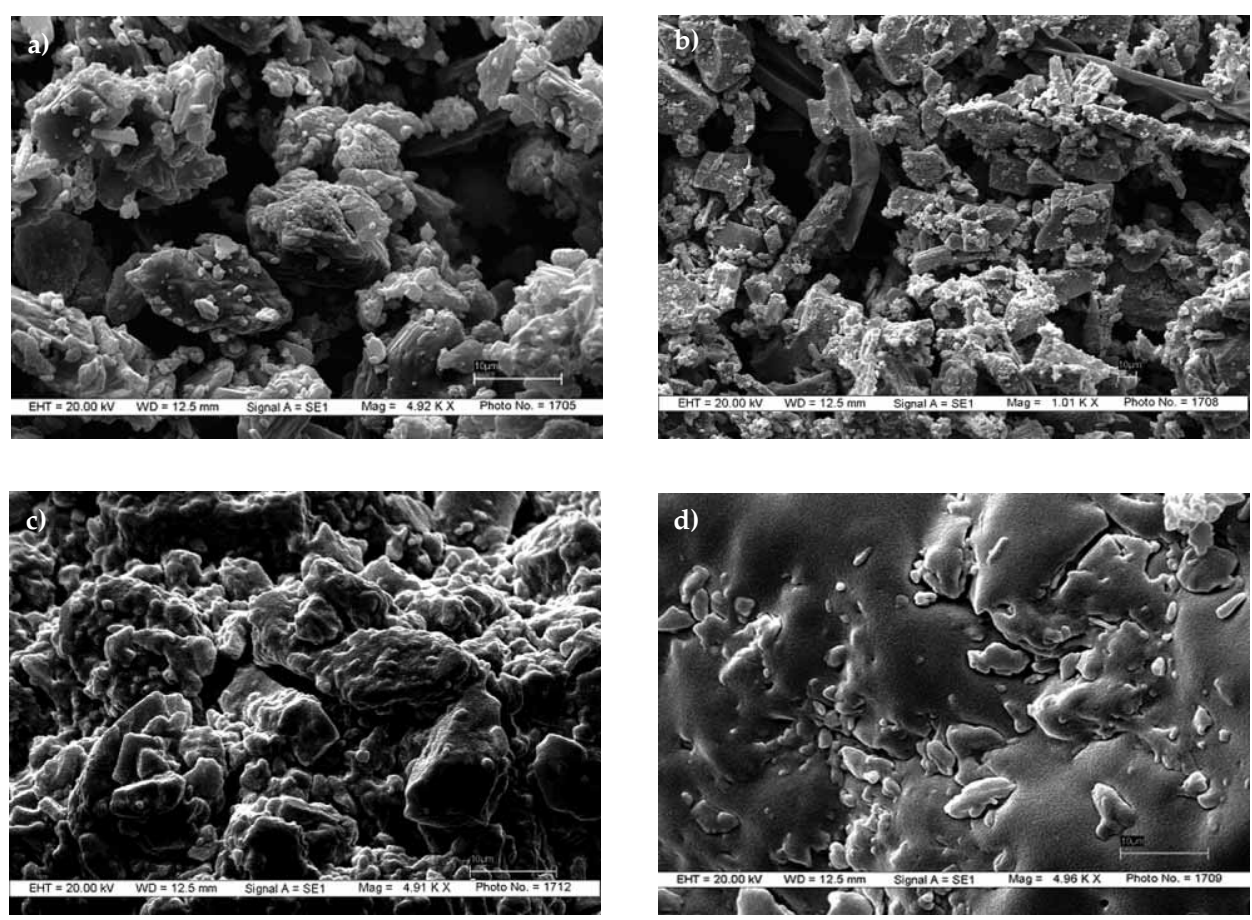

Fig. 4. Scanning electron micrographs of a) meloxicam, b) PEG 4000, c) physical mixture meloxicam/PEG (1:9), d) solid dispersion meloxicam/PEG 4000 (1:9).

Broadening of the peak at $2665 \mathrm{~cm}^{-1}$ due to overlapping between the OH of PEG 4000 and $\mathrm{NH}$ of the drug would perhaps result in increased solubility (13).

The morphology of the meloxicam/PEG 4000 system was studied by SEM. PEG 4000 particles were attached onto the surface of meloxicam crystals in case of F17 (physical mixture). In F18, there were no distinguishable drug and PEG 4000 particles, suggesting total miscibility of the drug with the carrier (Fig. 4).

\section{Evaluation of suspensions}

On the basis of release profiles and model independent parameters, meloxicam F18 was selected for suspension formulation based on the $2^{3}$ factorial design. The formulations were prepared and evaluated for dependent variables, viscosity and sedimentation volume (Table III). The formulation (S4) containing the higher level of methyl cellulose and lower level of sodium citrate exhibited a low sedimentation volume and higher viscosity whereas the formulation (S7) containing the lower level of methyl cellulose and higher level of sodium citrate displayed an increased sedimentation volume and decreased viscosity. Tween 80 at higher levels contributed towards the physical stability of the suspension. Levigation of drug particles with Tween 80 enhanced the wettability of hy- 
Fig. 5. DSC thermograms of: a) meloxicam, b) PEG 4000, c) meloxicam/PEG physical mixture and d) solid dispersion (1:9).

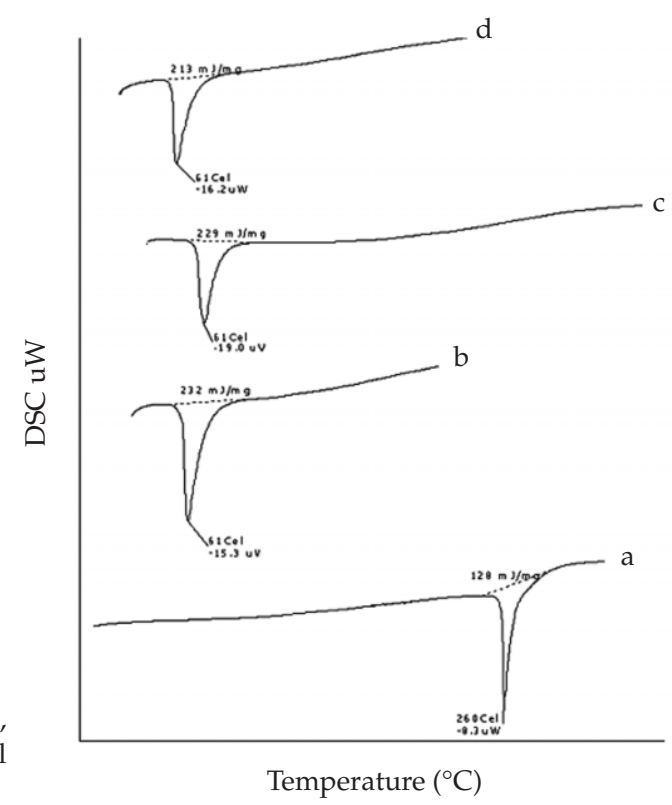

drophobic meloxicam, thus improving its contact with the dispersion medium and decreasing the rate of settling of the particles in combination with methyl cellulose present at a higher level. Thus to form a stable suspension it is desirable to have methyl cellulose and Tween 80 at high levels and sodium citrate at a low level. The other formulations designed exhibited intermediate sedimentation volume and viscosity values. Hence, S4 was selected as the optimized formulation and the in vitro dissolution studies performed in water and phosphate buffer $\mathrm{pH} 7.5$ showed $97.5 \%$ release in 90 min (Table IV) compared to $66.9 \%$ release in water at the same time point. The difference in release data may be attributed to enhanced solubility of the drug with increasing $\mathrm{pH}$.

\section{Validation of the experimental design used}

For validation of the design, the polynomial equation was deduced and an extra design checkpoint was made (14). The generalized polynomial equation is:

$$
Y=B_{0}+B_{1} X_{1}+B_{2} X_{2}+B_{3} X_{3}+B_{12} X_{1} X_{2}+B_{13} X_{1} X_{3}+B_{23} X_{2} X_{3}+B_{123} X_{1} X_{2} X_{3}
$$

Polynomial equations with significant coefficients for viscosity (Eq. 1) and sedimentation volume (Eq. 2) are:

$$
\begin{array}{r}
Y_{v}=34.25+1.25 X_{1}+4.25 X_{2}-0.25 X_{3}+0.25 X_{1} X_{2}-0.25 X_{1} X_{3}+0.75 X_{2} X_{3}-2.25 X_{1} X_{2} X_{3} \\
Y_{S}=0.4583-0.0167 X_{1}+0.0730 X_{2}+0.0276 X_{3}-0.0165 X_{1} X_{2}+0.0926 X_{1} X_{3}+ \\
+0.0631 X_{2} X_{3}+0.0881 X_{1} X_{2} X_{3}
\end{array}
$$




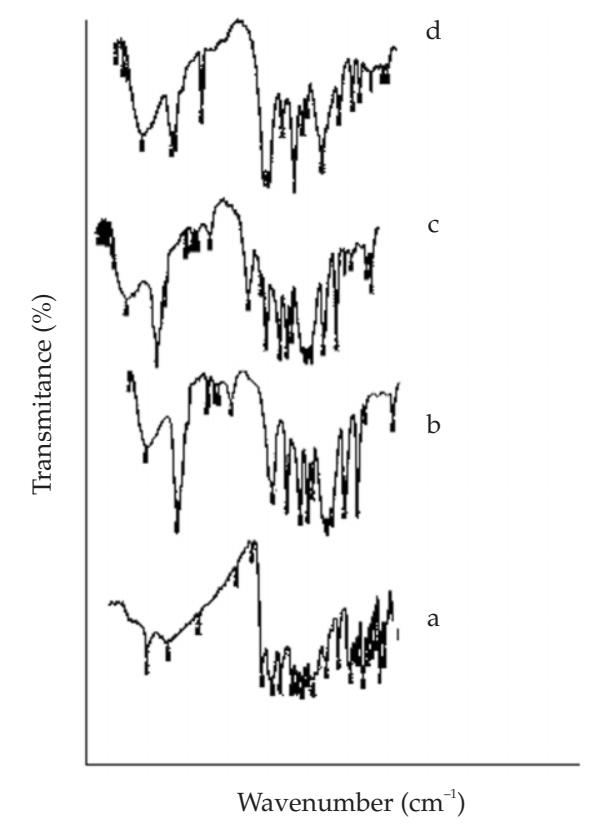

Fig. 6. FTIR spectra of: a) meloxicam, b) PEG 4000 , c) meloxicam/PEG physical mixture and d) solid dispersion (1:9).

where $X_{1}, X_{2}$ and $X_{3}$ denote the concentrations of Tween 80 , methyl cellulose and sodium citrate, respectively. The extra design check point with the following selected values of

Table III. In vitro drug release data for S4

\begin{tabular}{rcc}
\hline \multirow{2}{*}{ Time (min) } & \multicolumn{2}{c}{ Cumulative amount of meloxicam released $(\%)^{\mathrm{a}}$} \\
\cline { 2 - 3 } & \multicolumn{1}{c}{ Water } & Phosphate buffer $(\mathrm{pH} 7.5)$ \\
\hline 0 & $0.0 \pm 0.0$ & $0.0 \pm 0.0$ \\
5 & $8.4 \pm 0.3$ & $12.5 \pm 0.6$ \\
10 & $13.5 \pm 0.3$ & $41.3 \pm 0.6$ \\
15 & $19.8 \pm 0.3$ & $55.5 \pm 0.5$ \\
20 & $29.8 \pm 0.3$ & $75.0 \pm 0.5$ \\
30 & $40.2 \pm 0.3$ & $88.8 \pm 0.5$ \\
45 & $48.8 \pm 0.3$ & $93.9 \pm 0.5$ \\
60 & $56.0 \pm 0.3$ & $95.3 \pm 0.4$ \\
75 & $61.6 \pm 0.3$ & $97.5 \pm 0.4$ \\
90 & $67.0 \pm 0.3$ & $97.5 \pm 0.4$ \\
105 & $70.2 \pm 0.3$ & $75.0 \pm 0.4$ \\
120 & $70.2 \pm 0.3$ & $56.7 \pm 0.4$ \\
\hline
\end{tabular}

a Mean $\pm \mathrm{SD}, n=3$. 
independent variables $X_{1}=0.09, X_{2}=0.8$ and $X_{3}=1.0(\%, m / V)$ was made and the predicted values of $Y_{v}$ and $Y_{S}$ are 42 Pa s and 0.11 (sedimentation volume), which are similar to the experimental values of 42 and 0.12 pa s. These values validate the polynomial equation and hence the design of the experiment.

\section{CONCLUSIONS}

It can be concluded that improvement in the dissolution of the water insoluble drug meloxicam was achieved through solid dispersion using an inexpensive and GRAS listed hydrophilic carrier PEG 4000, which was formulated into a stable suspension that possessed superior bioavailability and which is suitable for geriatric population which exhibits an erratic absorption profile.

Acknowledgements. - Special thanks are due to Central Drug and Research Institute, Lucknow and IIT, Delhi, for spectral analysis.

\section{REFERENCES}

1. British Pharamacopoeia, $4^{\text {th }}$ ed., The Stationery office, London 2004, p. 1249.

2. B. Perissutti, F. Rubessa, M. Moneghini and D. Voinovich, Formulation design of carbamazepine fast-release tablets prepared by melt granulation technique, Int. J. Pharm. 256 (2003) 53-63; DOI: $10.1016 /$ S0378-5173(03)00062-0.

3. N. Seedher and S. Bhatia, Solubility Enhancement of COX-2 inhibitors using solvent systems, AAPS PharmSciTech. 4 (2003) article 33.

4. ICH Q3C Impurities: Guidelines for residual solvents; http://www.ichguideline.com.

5. J. Swarbrick and C. Boylen, Encyclopedia of Pharmaceutical Technology, Vol. 2, Marcel Dekker, New York 1990, pp. 262-263.

6. A. Fini, J. R. Moyano, J. M. Gines, J. I. Perez-Martinez and A. M. Rabasco, Diclofenac salts. II. Solid dispersions in PEG6000 and Gelucire 50/13, Eur. J. Pharm. Biopharm. 60 (2005) 99-111; DOI: 10.1016/j.ejpb.2004.11.005.

7. United States Pharmacopecia 24 / National Formulary 19, Asian Edition, USP Convention, Rockville (MD) 2000, p. 2303.

8. U. Ubaidulla, B. Senthilkumar, R. K. Khar and F. J. Ahmad, Studies on suspension of nimesulide solid dispersion: Development, characterization and in vivo evaluation, Indian J. Pharm. Sci. 67 (2005) 422-426.

9. A. Martin, Rheology, in Physical Pharmacy (P. Bustamante and A. H. C. Chun, Eds.), $4^{\text {th }}$ ed., B. I. Wavely Pvt. Ltd., New Delhi 1999, p. 424.

10. H. Parshad, K. Frydenvang, T. Liljefors, C. Cornett and C. Larsen, Assessment of drug salt release from solutions, suspensions and in situ suspensions using a rotating dialysis cell, Eur. J. Pharm. Sci. 19 (2003) 263-272; DOI: 10.1016/S0928-0987(03)00119-2.

11. P. Costa and J. M. S. Lobo, Modeling and comparison of dissolution profiles, Eur. J. Pharm. Sci. 13 (2001) 123-133; DOI: 10.1016/S0928-0987(01)00095-1.

12. D. Q. M. Craig, The mechanisms of drug release from solid dispersions in water-soluble polymers, Int. J. Pharm. 231 (2002) 131-144; DOI: 10.1016-S0378-5173(01)00891-2. 
13. N. Zajc, A. Obreza, M. Bele and S. Srcic, Physical properties and dissolution behaviour of nifedipine/mannitol solid dispersions prepared by hot melt method, Int. J. Pharm. 291 (2005) 51-58; DOI: 10.1016/j.ijpharm.2004.07.042.

14. M. C. Gohel and L. D. Patel, Improvement of nimesulide dissolution from solid dispersions containing croscarmellose sodium and Aerosil ${ }^{\circledR}$ 200, Acta Pharm. 52 (2002) 227-241.

$S A \check{Z} E T A K$

\section{Čvrsta disperzija meloksikama: faktorijalno dizajnirani dozirani pripravak za gerijatrijsku populaciju}

DEEPA PATHAK, SUNITA DAHIYA I KAMLA PATHAK

Cilj rada bio je poboljšati topljivost meloksikama u vodi pripravom čvrstih disperzija s hidroksietilcelulozom (HEC), manitolom i polietilen glikolom 4000 (PEG 4000) te razviti dozirani pripravak za gerijatrijsku populaciju. Za ispitivanje fizičke strukture pripravljenih čvrstih disperzija korištene su diferencijalna pretražna kalorimetrija, difraktometrija rentgentskim zrakama, FTIR i pretražna elektronska mikroskopija. Čvrste disperzije su u in vitro uvjetima pokazale bolju topljivost u odnosu na fizičku smjesu i čistu ljekovitu tvar. Najbolje oslobađanje lijeka $(100,2 \%)$. Postignuto je iz disperzija s PEG 4000 (omjer ljekovite tvari i nosača 1:9). Slijede manitol $(98,2 \%)$ i HEC $(89,5 \%)$ (isti omjer meloksikama i polimera). Čvrsta disperzija meloksikama s PEG 4000 prevedena je u suspenziju te optimirana $2^{3}$ faktorijalnim dizajnom. Najbolje oslobađanje ljekovite tvari postignuto je iz pripravaka koji sadrže veći udio etilceluloze i natrijevog citrata, odnosno Tween 80 .

Ključne riječi: meloksikam, čvrsta disperzija, hidroksietilceluloza, manitol, polietilen glikol 4000, $2^{3}$ faktorijalni dizajn, pripravak za gerijatrijsku populaciju

Department of Pharmaceutics, Rajiv Academy for Pharmacy, Mathura-281001, India 